\title{
Review of James Alfred Loader 'Proverbs 1-9' (Historical Commentary on the Old Testament), Peeters Leuven, 2014
}

\begin{tabular}{|c|c|}
\hline \multicolumn{2}{|l|}{$\begin{array}{l}\text { Author: } \\
\text { Pieter Venter }\end{array}$} \\
\hline \multicolumn{2}{|c|}{$\begin{array}{l}\text { Affiliation: } \\
{ }^{1} \text { Department of Old } \\
\text { Testament Studies, University } \\
\text { of Pretoria, South Africa }\end{array}$} \\
\hline \multicolumn{2}{|c|}{$\begin{array}{l}\text { Project Leader: P.M. Venter } \\
\text { Project Number: } 02350106\end{array}$} \\
\hline \multicolumn{2}{|c|}{$\begin{array}{l}\text { Description: } \\
\text { This research is part of the } \\
\text { project, 'Old Testament } \\
\text { Apocrypha, Pseudepigrapha } \\
\text { and Qumran Texts Studies' } \\
\text { directed by Prof. Pieter } \\
\text { Venter, Emeritus Professor, } \\
\text { Department of Old Testament } \\
\text { Studies, Faculty of Theology, } \\
\text { University of Pretoria. }\end{array}$} \\
\hline \multicolumn{2}{|c|}{$\begin{array}{l}\text { Corresponding author: } \\
\text { Pieter M. Venter, } \\
\text { pmventer686@gmail.com }\end{array}$} \\
\hline \multicolumn{2}{|c|}{$\begin{array}{l}\text { Dates: } \\
\text { Received: } 24 \text { Feb. } 2016 \\
\text { Accepted: } 30 \text { Mar. } 2016 \\
\text { Published: } 19 \text { Aug. } 2016\end{array}$} \\
\hline \multicolumn{2}{|c|}{$\begin{array}{l}\text { How to cite this article: } \\
\text { Venter, P.M., 2016, 'Review of } \\
\text { James Alfred Loader } \\
\text { "Proverbs 1-9" (Historical } \\
\text { Commentary on the Old } \\
\text { Testament), Peeters Leuven, } \\
2014 \text { ', HTS Teologiese } \\
\text { Studies/Theological Studies } \\
72(4), \text { a3385. http://dx.doi. } \\
\text { org/10.4102/hts.v72i4.3385 }\end{array}$} \\
\hline \multicolumn{2}{|c|}{$\begin{array}{l}\text { Copyright: } \\
\text { C 2016. The Authors. } \\
\text { Licensee: AOSIS. This work } \\
\text { is licensed under the } \\
\text { Creative Commons } \\
\text { Attribution License. }\end{array}$} \\
\hline \multicolumn{2}{|l|}{ Read online: } \\
\hline 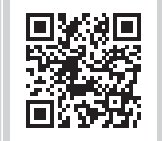 & $\begin{array}{l}\text { Scan this QR } \\
\text { code with your } \\
\text { smart phone or } \\
\text { mobile device } \\
\text { to read online. }\end{array}$ \\
\hline
\end{tabular}

Loader's commentary on Proverbs 1-9 belongs to the category of technical commentaries. It is evaluated in terms of similar commentaries written by scholars who focus on interpreting the original Hebrew text. The design of the commentary, the four essays included in the commentary, and the approach to the text is discussed. A final section deals with Loader's exposition of Proverbs 8. This section focuses on the problematic Hebrew terms qnh in 8:22 and 'amon in 8:30 and compares his interpretation with the opinions raised by other scholars in this regard.

\section{Commentary series}

Longman (2013:11) says that 'commentaries are addressed to specialised audiences'. According to Longman (2013:11), there are three categories of readers who use Biblical commentaries: laymen, preachers, and scholars.

The common man, 'interested much less in the matters of form, authorship, historical setting, social context, and philology' (Placher and Pauw s.a.:xii), will look for the application of the biblical text to today. He or she will use a commentary from series like the 'OT Study Bible' (OTSB), 'Hearing the Message of Scripture' (HMS), The 'Smyth \& Helwys Bible Commentary' (SHBC), and 'Belief: A Theological Commentary on the Bible' (BACB).

Pastors, church teachers, and students of the Bible will use a commentary from series like the 'John Phillips Commentary' Series (JPC), the 'Mentor Commentary' Series (MC), 'The Expositor's Bible Commentary' (EPC), 'NIV Application Commentary' Series (NIVAC) and 'Brazos Theological Commentary on the Bible' (BTCB). In this second category of commentaries, they will find an introduction to a biblical book, its outline, textual commentary, transliteration and translation of Semitic and Greek words, and exposition of the contents. This type of series 'offers doctrinally sound interpretation that emphasizes the practical application of Bible truth' (Olive Tree n.d.:n.p.).

The third category is intended for scholars. Loader (2014:IX) discerns between 'technical commentaries' and 'commentaries intended for a wider readership'. Loader's commentary on Proverbs 1-9 is a technical commentary. This is inter alia illustrated by the authors he quotes and refers to in his commentary. Among them ${ }^{1}$ are, in order or frequency, Michael V. Fox $\left(2000^{2}\right)$, Bruce Waltke $\left(2004^{3}\right)$, Crawford H Toy $\left(1899^{4}\right)$, Berend Gemser $\left(1963^{5}\right)$, RN Whybray $\left(1994^{6}\right)$, Roland E Murphy $\left(1998^{7}\right)$, and William McKane $\left(1970^{8}\right)$.

1.See the index of authors (Loader 2014:403-406) for a full list of scholars quoted.

2.In the series, 'Anchor Yale Bible Commentaries' (AYB). This series 'emphasizes philology, historical background, and text, rather than theology' (Longman 2013:15). Fox interprets Proverbs 1-9 against the background of Israel's intellectual history.

3.In the 'New International Commentary on the Old Testament' (NICOT). This series is 'evangelical and scholarly but written in a way that lay people can understand' (Longman 2013:20). Loader uses this publication for its excellent technical quality.

4.In the series, 'International Critical Commentary' (ICC), called by Longman (2013:18) 'a series presenting highly technical studies of philology and text'. Although more than a century old, this commentary is still useful for its highly technical nature.

5.In the series, 'Handbuch zum Alten Testament' (HAT) with its philological-historical focus.

6.In the series, 'New Century Bible Commentary' (NCBC). In the reprint of the 1972 edition Whybray shows how the tradition of collecting wisdom aphorisms was modified to conform to the slogan of the 'fear of the Lord'. He also indicates that some sections of Proverbs agree to instructions from Egypt and Mesopotamia.

7.Volume 22 in the 'very learned' (Longman 2013:22) 'Word Biblical Commentary' (WBC, not included in Loader's [2014:XII-Xiii] list of Abbreviations) series. The 'Editorial Preface' (Murphy 1998:X) states that this series makes 'the technical and scholarly approach to a theological understanding of Scripture understandable'. Loader follows more or less the same pattern for his exposition as this series, except for an additional explanation summarizing the analysis within the context of the specific book, its meaning in the OT and NT, its except for an additional explanation summarizing the analysis within the context
place in the entire canon, and the theological relevance to general biblical issues.

8.McKane (1970) presents a 'new approach' to Proverbs in the critical theological 'Old Testament Library' (OTL) series. This series is an English continuation of the German series 'Das Alte Testament Deutsch'. Written 'in the critical tradition' (Longman 2013:21), McKane's commentary achieved international standing because of its thorough exploration of Proverbs and of the wisdom literature in the context of the Ancient Near East. 


\section{The Historical Commentary on the Old Testament series}

Loader's commentary on Proverbs 1-9 forms part of the series Historical Commentary on the Old Testament (HCOT). This can be called a 'technical' (Loader 2014:IX) series. It continues the Dutch series 'Commentaar op het Oude Testament'. In the Guidelines for Contributors to the HCOT series, dated July 2007, the editorial team explains what is meant by 'Historical' in the name of the series. As 'revelation was recognized in the context of ordinary human history, culture and language' (Guidelines 2007:1), there is a historical aspect to the text. Not only the historicity of the context but also the history of the text itself has to be kept in mind. In this process, 'a clear distinction should be made between the date of a certain tradition and the historical events it purports to relate' (Guidelines 2007:2). The 'Old Testament is the product of a long process of transmission of various traditions that were actualized over and over again in the history of ancient Israel' (Guidelines 2007:1). This intends 'explicit attention to the history of interpretation of biblical tradition in all its stages, both within and without the Hebrew canon' (Guidelines 2007:2). There are historical stages in the interpretation of the text and these have to be put in inter textual dialogue. Although 'the final stage of the text should be assigned the primate' (Guidelines 2007:2), every historical level of interpretation is of importance in the exegetical exposition. This includes the Nachgeschichte (post history) of the text in the history of Jewish and Christian interpretation. Reference to other passages in the Old Testament (OT) and New Testament (NT), regarded as later applications of actualisations of the text, should be included.

Standing in the 'christian exegetical tradition' (Guidelines 2007:2), the commentary series 'is intended not only for Old Testament scholars, but also for ministers and other interested parties'. In the organisation of the commentary, every pericope is to be preceded by the author's translation of the text and a 'section called "Essentials and Perspectives" in which the author summarizes the results of the exegesis in non-technical language' (Guidelines 2007:2) in which 'not even Hebrew or Greek' (Guidelines 2007:2) is used (obviously, for those who cannot read these classic languages). This should lead to the next section, 'Scholarly Exposition' (Guidelines 2007:2). In this section, 'everything that brings the then existing world nearer to the reader' (Guidelines 2007:2) should be included. A structural analysis of the text as 'one step toward recovering the meaning of the text in history' (Guidelines 2007:2) is to be included. Text critical, lexicographical, or grammatical problems are only to be discussed if they are indispensable in the explanation of the text. Questions of dating, authorship, or method is left to the discretion of the contributor.

\section{Loader's commentary - his Introduction}

Loader follows these Guidelines, imprinting on it his own scholarly insights. After a Preface setting out the contribution of this commentary to the ongoing research on Proverbs 1-9 (Loader 2014:IX-X), there follows an outline of abbreviations used (Loader 2014:XI-XIII) and a bibliography of publications referred to in the commentary (Loader 2014:XV-XXVIII). This is followed by an Introduction (Loader 2014:1-50) and the Commentary of the contents of Proverbs 1-9 proper (Loader 2014:51-401). At the end of the commentary, an index of authors (Loader 2014:403-406) is provided as well as a list of traditional Jewish and Patristic sources (Loader 2014:407). Unfortunately, the publication does not include a list of Scriptural references. This would have added much to the use of this publication.

In the Preface, Loader (IX-X) identifies two issues with regard to which his commentary can contribute to the research on Proverbs. First, being an 'exegetical commentary' (Loader 2014:X), it aims at indicating the 'amplitude' of the text of Proverbs by studying the 'philological, structural and compositional levels' (Loader 2014:IX) of the text. This is done in dialogue with existing scholarly publications (see above). Secondly, he pays attention to 'text reception' (Loader 2014:X), especially chapter 8 (see below), and the influence it has had on later generations of readers.

The Introduction (Loader 2014:1-46) is divided into eight different sections ( $\$ 1-8)$. Sections $1-7$ deal with the customary introductory questions. The last section ( $(8)$ is subdivided into four essays.

The first section $(\S 1)$ outlines the way this commentary is organised. Loader follows the HCOT Guidelines by using the set scheme of translation, essentials and perspectives, exposition one (indicating aspects like structure, genre, style, literary criticism, and theme), and exposition two (detailed exegesis). He divides the first nine chapters of Proverbs into 16 units, and follows the same scheme of investigation in each of these units. Ten of these units are called 'lessons', the rest 'poems'.

The genre of Loader's (2014:2) commentary is 'commentary on the Hebrew text'. He therefore uses either the BHS or BHQ readings. In some cases, he agrees with Tov and refers to a Hebrew Vorlage (cf. Loader 2014:178). Although the Hebrew text is usually quoted in a vocalised form, there are cases in which it is printed without any vocalisation. ${ }^{9}$ In line with the Guidelines, the author also presents his own translation of all quoted Hebrew texts. ${ }^{10}$ Loader very often refers to, compares with, and quotes from the versions of the Septuagint, Syriac Peshitta and the Aramaic Targum, and alternate forms of the Masoretic text (Qere en Ketib readings). What is obvious throughout the commentary is Loader's conservative use of text emendations.

Latin terminology is used many times in the commentary. It is noticeable that the author is every time at pains to give a

9.Cf. Loader 2014:151, 214. I could not find any rationale for this alternating in vocalization of the Hebrew text.

10.The Hebrew of Proverbs $24: 33-34$ and $6: 10-11$ is quoted on page 264 , but the author's translation omitted. 
translation and explanation of the terms he uses. ${ }^{11}$ In this section ( $§ 1)$, he explains the (Latin-based) poetic terms he uses. When referring to the linguistic analysis of other commentators he often differs from them and even corrects their analyses. ${ }^{12}$ With this commentary, Loader marks out an exclusive niche for himself that can be equalled by only a few.

Within the larger context of the commentaries indicated above, his learned commentary diminishes the quantity of users who can really benefit optimally by his publication. Although he explains the terms used, there are many instances in which extra linguistic knowledge is needed to follow the arguments in the commentary. His commentary requires more than the usual skill of just an intelligent reader. Especially in the exegetical sections ('Exposition 2'), the Hebrew text used requires the reader to be able at least to read Hebrew. Other commentaries usually provide the Hebrew text in a transliterated form (not that it would make any sense for readers not trained in biblical Hebrew). The adroitness of the author in Semitic linguistics is both the strong point of his commentary as well as its weak point, depending upon who uses this commentary. Loader's commentary does not only belong to the third category of commentaries above, but also to the upper level in that category. It is therefore in Loader's (2014:IX) terms a highly 'technical' commentary. For those experienced in the field of Hebrew linguistics, this commentary will be superior. For the general reader, it will be less useable.

In §2 ('Place of Proverbs in the Major Canons', Loader 2014:4-6) and $\S 7$ (The Relevance and Message of Proverbs, Loader 2014:12-15), the issue of Proverbs' role in ecclesiastical theology is discussed. This usually neglected section of the Bible stands on an equal footing with all other books in the canon and is 'theologically relevant' (Loader 2014:12). Although different in style from the so-called revelatory theology found in present day biblical theologies, sapiential literature is not dissimilar 'in essence' (Loader 2014:14) from the rest of the Bible. Issues raised here are taken up again in the third essay ( $\$ 8.3$ Loader 2014:28-39, see below).

In §3, Loader (2014:7) agrees with most scholars that 1:1-9:18 is an 'introductory collection of poems'. It can be divided into '[th]ree time three lessons [that] either follow or are draped around poems' (Loader 2014:8). There are 10 'lessons' in Proverbs 1-9. A preface in 1:1-7 is followed by the first lesson in 1:8-19. A poem in 1:20-33 is followed by three lessons in $2: 1-3: 26$. A second poem $(3: 27-35)$ introduces the next three lessons in 4:1-27. The lesson in 5:1-23 is followed by a poem (6:1-19), again followed by two lessons (numbers nine and 10 in 6:20-7:27). The section comes to an end with two poems in 8:1-36 and 9:1-18 (cf. Loader 2014:8).

Regarding the date of the book of Proverbs (§4), Loader is of opinion that the book was finalised by the start of the second

11.For example, Loader (2014:218) explains the term figura etymologica as "a verb with an etymologically related noun as object'.

12.For example, Loader (2014:331) corrects Fox's description of 8:10a as 'an elliptical vetitive'. It is a plain imperative used here, only followed by an elliptical vetitive. Examples can be found all over the commentary, but this serves only as one example. century BCE, predating Ben Sira. Accumulating material from older monarchical times, the book of Proverbs was completed by late Persian or early Hellenistic time ${ }^{13}$ (cf. Loader 2014:9).

As far as provenance is concerned (§5), Loader (2014:10) discerns between the lessons and poems in Proverbs 1-9. The poems (1:20-33; 3:27-35; 6:1-19; 8:1-36 and 9:1-18) come from different authors. In the 'cumulative process of growth' (Fox's term, referred to by Loader 2014:10), the poems were added to the lessons to construct an 'architectonic symmetry' in the final text (Loader 2014:10).

What Loader means by this 'architectonic symmetry' is illustrated by the way the different compositions in Proverbs 1-9 are structured and the way they are linked to each other. Discourse is the 'main genre of Prov 1-9' (Loader 2014:65), and accommodates fluctuation in the types of communication used. The discourse in 1-9 is 'built up much like the wellestablished classical discourse of Greek rhetoric' (Loader 2014:65).

Many of the separate units are structured according to a 'threefold rhetorical pattern of introductory appeal, argument and conclusion'14 (Loader 2014:87). A structural plan was used most of the time to create the units. In the case of 3:1-12, as an example, the unit is not a mixed hodgepodge of items, but rather a 'conscious compositional work with available materials' (Loader 2014:142). Proverbs 6:20-35 is not disjointed but a 'coherent argument' (Loader 2014:273).

A technique used innumerable times in Proverbs 1-9 is that of chiastic structuring. In an extended note on chiasm, in smaller print (see below), Loader (2014:77) remarks that the technique of chiasmus is used 'to draw attention through conspicuous integration, by means of which it may serve an elevated style, impress and aid memory'. Loader has a very much open-ended definition of chiasmus. He follows a multilevel approach in identifying chiasms in the text. Chiasms are not restricted to words only, but operate on both formal and syntactical levels. Concentric patterns or a chiasmus is formed when similar word forms are repeated crosswise, semantic fields inverted and repeated, and ideas reiterated in an ABBA form. Even linguistic compositions can form a chiasmus. For example, a crosswise structure of Couplet-Quatrain-Quatrain-Couplet (cf. Loader 2014:88) forms a chiasmus. Even sounds repeated in an inverted order can form a concentric pattern. As a figure of style chiasmus can even point out opposites 'as is often the case in the Books of Qohelet and Esther' (Loader 2014:133).

This broader perspective on a term like chiasmus is connected to Loader's lateral view of the text. He follows a multidimensional approach to the text. In the case of Proverbs

13.Alexander the Great defeated the Persians at Issus in 333 BCE. The era between 333 and 164 BCE is known as the Hellenistic era as far as Palestine is concerned. Late Persian and early Hellenistic time would rather be fourth or third century BCE.

14.Also indicated as 'Structure of address, substantiation, imperatives, and statements' (Loader 2014:224) in 4:20-27, or 'threefold structure of introduction, lesson and conclusion' (Loader 2014:233) in 5:1-23. 
2:1-22, as an example, different aspects have to be kept in mind to analyse the structure of the poem: 'logical flow of its thought, the grammatical construction of the language it uses and the strophic composition of its poetry are all aspects of the way it is built up' (Loader 2014:103). There are a host of issues in the text: 'structure, style, syntax, motifs and stylistic forms' (Loader 2014:103). His analysis of 6:20-35 is based on both formal considerations (such as syntax, pronominal markers, and conjunctions) and considerations relating to the contents (logical unfolding of the argument) (cf. Loader 2014:274). Loader does not work on a structural level only. His analysis operates with the 'overlooked interface between the synchronic analysis of a composite text and its diachronic aspect as well as the significance of this for its meaning (Loader 2014:515).

When it comes to the link between the different units in the final text, there are also a multiplicity of possibilities to form larger units. Loader warns against over-refining the 'compositional design' of Proverbs 1-9, but admits that it is clear that there is a 'network of related motifs and themes [which] show an appreciable degree of intratextual coherence in the first collection of the book' (Loader 2014:199). Some examples will suffice. Proverbs 1:20-33 complements 1:8-19 by extending its warning into the issue of the neglect of wisdom (cf. Loader 2014:87). Proverbs 2:1-22 continues 'the train of thought' (Loader 2014:102) of Proverbs 1-9. Proverbs 3:13-26 is a 'next building block in the collection of Chaps. 1-9' (Loader 2014:164). The editor(s) of the final text forged former independent units into the final product 'in a purposeful way' (Loader 2014:166). The three units 3:1-12, 3:13-26, and 3:27-35, are interlinked by the same 'religious motivation' (Loader 2014:184), highlighting three different aspects of wisdom. In the case of 4:10-19, it is unclear how it either links to the previous and following units, or should be demarcated (cf. Loader 2014:212). In the case of 4:20-27, however, Loader proposes that there is a thematic link with the preceding (4:10-19) unit (cf. Loader 2014:223). Proverbs 6:1-19 forms an intermezzo between 5 and 6 , but the subject of 5:1-23 is picked up by 6:20-35 (cf. Loader 2014:272). Proverbs 8:1-36 'does have a specific place in the architecture of the whole book' (Loader 2014:318). Proverbs 9:1-18 takes up 'several motifs and words from the poems in the earlier chapters' (Loader 2014:377). This poem is linked 'backwards as well as forwards' (Loader 2014:377), introducing the reader to the options from Proverbs 10:1 onwards. ${ }^{16}$

Several efforts were launched in the past to find one or another link between the different units of Proverbs 1-9. Loader refers to Fox's use of the idea of a 'ground metaphor' (2014:66) and a 'capstone' at the end of the units (2014:184). Back in 1981, I (Venter 1981) proposed a type of Motivkonstellation (motif construction) consisting of 'wisdom', 'proverbs', and 'life' in the 20 units in Proverbs 1-9. This was my conclusion when I made a Längeschnitt (linear cut) through the 15.See in this regard, his exposition of Proverbs 1:1-7 (Loader 2014:51-53). 16.With regard to Proverbs 3:6, Loader agrees with Fox that, here, knowledge, piety, and action are blended into one principle. This stands simultaneously, as Fox is quoted, 'at the core of the message of Proverbs 1-9' (Loader 2014:154). structured identified 20 units of these chapters. Loader represents a shift away from this modernistic centralised approach that looks for an atomic model in which everything circles around one kernel. He agrees with scholars like Hatton that 'the contradictions in the book are no accident or liability, but intrinsic to it' (Loader 2014:328). The composition of Proverbs 1-9 is to be viewed rather from a post-modern perspective of paradox and tension. ${ }^{17}$ Proverbs 10:1-31:31 presents an even larger problem with regard to cohesion. It will be interesting to see how Loader approaches this problem in his planned second volume on Proverbs 10-31. It will probably also be addressed by Christopher Ansberry, in his coming Proverbs commentary, number 16 of the Evangelical Exegetical Commentary series, ${ }^{18}$ or by Bernd U. Schipper' ${ }^{19}$ forthcoming commentary in the Hermeneia ${ }^{20}$ series.

Regarding literary criticism, Loader is usually very conservative. The Guidelines recommend that attention be given to the history of the text. There was a phase in research when text emendation was in vogue. Loader often quotes scholars' proposals for changing or deleting the text, but always tries and defends the present text. He usually argues that some other reasons could be found for problematic readings. Most of the time, he finds the text logical as it is, so that it is unnecessary to change it (cf. Loader 2014:176). He does take textual criticism really seriously, but is very careful and only 'emend[s] when absolutely necessary' (Loader 2014:11).

An example in this regard is Loader's notes on the literary criticism of Proverbs 3:1-12 (Loader 2014:144-145). With regard to the historical dimension of the present Proverbs 3:3 and the problems with its metrical arrangement, Loader prefers to find a rationale for the form of the present text by studying 'different levels of meaning'. Rather than doing 'repair surgery to the text' (Loader 2014:144), he prefers to not emend the text, but rather find a reason why the text is the way it is. The text is often 'logical as it is and should therefore not be changed' (Loader 2014:176).

The exposition of Proverbs 3:13-26 can serve as another example in this regard. In his reconstruction of the editorial stages of the verse, Loader conjectures that 3:3a was inserted 'to suit a context that integrates wisdom and piety' (Loader 2014:145). What is found in Proverbs 3:3a existed already before the redactional time and was built into the unit 'much along the same lines as the composition of the Book of Proverbs as a whole' (Loader 2014:144) were structured. The couplet of 3:19-20 is not misplaced like other commentators (Murphy 1998) proposes, but is rather a 'striking enrichment of the poem' (Loader 2014:174) that highlights 'the cosmic dimension of wisdom' (Loader 2014:174).

17.This is the basic thesis in his Polar Structures in Qoheleth. Cf. Loader 1979.

18.This series is written from an evangelical perspective.

19.Thomas Krüger's (2016) remarks, in his German review of this commentary for RBL, that Bernd U. Schipper's contributions are absent in the commentary.

20.According to Logos (n.d.:n.p.), this series utilises 'the full range of philological and historical tools, including textual criticism (often slighted in modern commentaries), the methods of the history of tradition (including genre and prosodic analysis), and the history of religion'. 
A third example can be found in the exposition of Proverbs $8: 11$ and 13. In the case of 8:11, Loader (2014:322) argues that verse 11 can be an 'intentional quote' and need not be deleted. ${ }^{21}$ The first half of 8:13 can be read as two stichs, the first connecting 'neatly' to the previous verse 12 and the second to the last half of verse 13. Even the section of verses 22-31 expounding wisdom's cosmologic importance, seen by many like Whybray, Ringgren, and McKane as a later addition, could have been from the same author of the rest of the speech. That author wanted to augment wisdom's motivation of her importance in daily life with a section on her primeval role. With remarks like these, Loader shifts the issue of text history to a much smaller time span than usual and tries to evade the hypothetical question of a multiplicity of authors for a text.

In two cases (Prov 2:1-22 22 and 8:1-36 23 ), Loader adds formal excursus to the unit under discussion. More extended notes all through the commentary are in smaller print, dealing with a very wide area of research. They are included for 'collateral technical discussion or supporting argument' (Loader 2014:2). These notes usually broaden the argument, by quoting from the word of peers, or introduce relevant investigation conducted on a specific subject. In some cases, the section in smaller print gives occasion for lengthier debates on an issue. ${ }^{24}$ The footnotes are more specific and usually refer to sources quoted or reflect the (sometimes different) views of other scholars on the same issue. These notes, along with shorter notes and footnote references gave the author the freedom to state his view on a 'broad spectrum of issues' (Loader 2014:4) in Proverbs.

The extended notes deal with subjects like who the real father in Proverbs is (Loader 2014:69), chiasmus (Loader 2014:76-77 see above), conjectural emendations (Loader 2014:78), morphologic problems (Loader 2014:92), text critical problems ('House' in Proverbs 2:18; Loader 2014:129), literary critical problems (Proverbs 3:3; Loader 2014:145), Paul's remarks on law suits in the NT (Loader 2014:192), the 'message' ${ }^{\text {'25 }}$ of Proverbs 4:1-9 (Loader 2014:208), Von Rad and the Joseph story (Loader 2014:254-255), 'Masoretic vocalisation' of Proverbs 6:23-24 (Loader 2014:278), ivory carvings from Phoenicia related to Proverbs 7:6 (Loader 2014:301), textual criticism and glosses with regard to Proverbs 8:10 (Loader 2014:331-333), Melanchthon's exposition of Proverbs 8:22 (Loader 2014:349), the order of natural phenomena in Proverbs 8:24-26 (Loader 2014:351), and different proposals for the translation of the Hebrew 'amon in Proverbs 8:30 (Loader 2014:356-360) (see below).

21.Loader (2014:332-333) takes up this issue again in his argument printed in smaller type. Basing his argument on Hebrew manuscripts and different versions, keeping in mind 'sensible intertextuality', and insufficient proof, he rejects proposals for emendation of the verse.

22.The strange woman (Loader 2014:136-140).

23.The reception of Proverbs 8 (Loader 2014:367-375).

24.Cf., as an example, Loader (2014:334) presents a step-by-step debate with the argument of Fox that the nominal status of $8: 12 \mathrm{a}$ is related to royal inscriptions and divine declarations.

25.This strange note is the only one on a 'message' referring to present-day preaching in this text-oriented commentary dealing with the text and its historica interpretation. It rather belongs in a commentary series like Interpretation.

\section{Loader's Four Essays on Proverbs}

Included in the Introduction are four essays. These pertain to all of the book of Proverbs, not only the first nine chapters of the commentary. The essays deal with the social setting of wisdom, the concept of order, the deficiency of revelation in wisdom literature, and the idea of retribution and its limits.

1. Scholars proposed either a school or a court background as Sitz im Leben (life situation) for Proverbs. The father referred to in Proverbs could have been the person who played 'the well-known father role of home education' (Loader 2014:70). Loader (2014:15-19), however, argues that the book of Proverbs in its final form presents traditional folk wisdom filtered through a court tradition. Evidence of both forms of wisdom is found in Proverbs. The longer compositions in Proverbs 1-9 manifest 'some institutionally conceived education' (Loader 2014:19).

2. Reviewing the Forschungsgeschichte (history of research) on the concept of order and the contributions of scholars like Murphy, Westermann, Crenshaw, Hermisson, Gese, Schmid, and Fontaine, Loader (2014:28) states in his second essay: '[w]hen the sages speak, they speak of order'. The order principle as heuristic concept for experiencing reality is present in all of Israel's wisdom, be it in the form of didactic wisdom (Prov 1-9) or of aphoristic wisdom (Prov 10-31).

3. In his third essay, Loader (2014:28-39) addresses the longstanding problem of wisdom literature's place in Biblical theology. This essay continues the subjects indicated in $\S 2$ ('Place of Proverbs in the Major Canons') and $\$ 7$ ('The Relevance and Message of Proverbs') above. Traditionally, wisdom literature has been excluded from biblical theology because it is per definition not revelatory. Loader (2014:28), however, argues that 'sapiential literature has a major theological relevance in this regard'. Loader (2014:65) states 'that Israel's wisdom tradition is not at odds with the other literature in the Old Testament'. ${ }^{26}$ The issue of land, for example, is a motif in Deuteronomy. The same motif occurs in Proverbs, but is given a different interpretation (cf. Loader 2014:135). Similar views on law are found in Proverbs and in Deuteronomy 15:9,13 (cf. Loader 2014:189). The calling motif in 1:20-33 shows striking similarities to the acts of the prophets (cf. Loader 2014:91). Loader therefore explores and criticises the customary bifurcation in religion studies between natural and revelation theory. He opposes H. D. Preuss' rejection of Proverbs as theology and rather joins James Barr's reflection on the issue of Biblical theology. He argues for a 'cohabitation of natural religious thought and revelation' (Loader 2014:29). For him, these two types of 'theology' can even be 'different expressions of the same thing' (Loader 2014:30). He argues that wisdom is 'another form of revelation' (Loader 2014:38), a 'leaner kind of God-talk' (Loader 2014:39), following another line of communication between God and man, than direct revelation, but still remains to be revelation. In 'balanced

26.Contrary to this view, Toy (1899:xvi), as example, states traditionally for his time that Proverbs' 'position is thus sharply distinguished from that of the Prophets, the Law, and the Psalmists... 
theology ...[and] balanced life' (Loader 2014:39) both are needed. This is a very welcome move away from the outdated historical, evolutionary Old Testament theologies that were so dominant during the earlier twentieth century.

4. Another generally adopted term in sapiential research is the term 'retribution'. In the fourth essay, Loader (2014:39-46) explores the nexus between deed and consequence in wisdom literature. Their experience of a primal order controlling all of reality brought to the Israelites to the conviction of a link between acts and its results. Reality, however, cannot always be explained in terms of this deed-consequence connection only. The nexus could never be seen as a rigid retributive connection. There are limits to the link between the two (cf. Loader 2014:193). Wisdom as human undertaking has its ultimate source in God (cf. Loader 2014:116). ${ }^{27}$ There is, therefore, not only an automatic, created mechanism by which the world reacts to human behaviour, but also one with which God is personally involved (cf. Loader 2014:195). Loader indicates from examples found in Proverbs 10-31 that, in some cases, the nexus could not be denied, but in other cases, it was simply not present. In the strongly erotic Proverbs 5:1-23, a close nexus between deed and consequence is clearly perceived as personal retribution by God (cf. Loader 2014:234). Loader (2014:46) refers to the 'mysterious side of the issue' explored in the sceptical wisdom literature, especially.

\section{Loader's exposition of Proverbs 8}

In the Preface, Loader points out that Proverbs 8 has had an exceptional and long reception in the history of exegesis. One of the aims of the HCOT commentary series is, indeed, to draw attention to text reception. Proverbs 8 is, therefore, 'especially relevant' (Loader 2014:X).

Loader (2014:316) calls Proverbs 8:1-36 'Wisdom's Eulogy'. Within the overall structure of Proverbs 1-9, Loader (2014:8) interprets this as the second last poem following upon the three lesson-poem clusters in 1:20-3:26, 3:27-4:27, and 5:1-7:27. Following the set pattern of his commentary, a translation of the Hebrew text (Loader 2014:316-318) is followed by a section on essentials and perspectives (Loader 2014:318-319. The following section (Loader 2014:319-324), called Exposition I, presents his notes on the structure, literary criticism, genre and style, and theme of the pericope. Exposition II (Loader 2014:324-367) presents his exegesis according to the subsections he already indicated in his translation (Loader 2014:316-318). Each of these sections $(8: 1-11 ; 8: 12-21 ; 8: 22-31$ and 8:32-36) is discussed either verse by verse or according to the larger verse clusters found in the specific subsection. The chapter ends with an excursion on the reception of Proverbs 8.

The author's translation at the beginning of the chapter indicates that he parses the pericope into four parts. His

27. Loader refers to the books of Esther, the Ruth Joseph story (Gen 37-50), and the Succession Narrative (2 Sam 9-1Ki 2) in which God's role is clear. He has done extensive research on these books.
English translation reads fluent, reflecting the way the original Hebrew is numbered and printed as two (or three) lines comprising hemistiches (poetic lines forming together one stich). The rationale for the demarcation of Proverbs 8 into four units is presented later on in Exposition I.

In the section on essentials and perspectives (Loader 2014:318-319), bibliographical information is provided on related publications on Proverbs 8. Loader then indicates several issues raised by commentators when discussing this 'controversial chapter' (Loader 2014:318). These include the pre-existence of wisdom, her personification, the problem of interpreting this chapter as an interlude within the larger context of Proverbs 1-9, and the bold claims wisdom makes in this chapter that resulted in a wide variety of interpretations in Jewish and Christian receptions. The contents of this poem had 'implications on the literary level as well as on the levels of reception history and theology' (Loader 2014:319). ${ }^{28}$

In the first exposition, Loader deals with introductory questions usually addressed in commentaries. He calls the instruction of chapter 8 'a substantiated self-recommendation' (Loader 2014:323). The usual term of 'self-laudatory instruction' is not fully representing the other two wisdom speeches in Proverbs 1:20-33 and 9:1-6. The 'auto-eulogy' (Loader 2014:323) in 8:12-21 and 8:22-31 includes a validation not found in the other two wisdom speeches. A term like 'substantiated self-recommendation' (Loader 2014:323) would therefore be a better term for the genre used here.

Loader indicates the way the four sections in 8:1-36 are structured as admonitions, a first in verses 1 to 11 and a second in verses 32 to 36 . These two form an outer circle in the composition. In the centre of the speech, he marks out two substantiating sections that he calls 'speech cores'. In the first (8:12-21), wisdom refers to her role in the present world. In the second (8:22-31), core wisdom refers to her role in the primeval world. In the first and last sections, wisdom's role is 'explicated'; and in the two middle sections, it is 'authenticated' (Loader 2014:363). These four sections stand in an ABBA chiastic relationship.

Loader's remarks on Proverbs 8 can be compared to the opinions of other commentators on Proverbs to outline his specific approach to the text. In his commentary, Fox quotes the original Hebrew text in transliterated form. No knowledge of Hebrew is therefore needed to use his commentary. ${ }^{29}$ The notes on 'more technical investigations' (Fox 2008:n.p.) can even be ignored. This enables 'different kinds of reading and study' (Fox 2008:n.p.). This does not, however, exclude considerations of philological problems and theories on interpreting the text. The Anchor Yale Bible Commentaries include lengthy text critical notes on each chapter discussed. Fox also pays attention to literary critical problems in his commentary, referring inter alia to ancient versions. In the 28.Cf. the excursion in Loader 2014:367-375.

29.Although intended to broaden the scope of readers, the transliterated text is a meaningless combination of letters to readers not knowledgeable in Hebrew. They will have a commentary with only the non-technical information of really any use. 
case of Proverbs 8:1-36, he recognises 'a symmetrical and hierarchical envelope structure' (Fox 2008:n.p.). He gives attention to linguistic aspects of the unit showing 'balance and symmetry' (Fox 2008:n.p.). The difference from Loader, however, concerns analysing the poetic structure of this 'Interlude'. Loader's analysis focuses on the Hebrew poetic structure and his linguistic remarks probably surpass those of Fox.

In his Exposition II, Loader refers to the extraordinary attention readers paid to Proverbs 8, especially the section of 8:22-31..$^{30}$ According to Loader (2014:344), this 'second speech core' is totally integrated in the rest of the chapter in the present text. Two verses caused extraordinary differences in the exegetical history. In 8:22, the problem is found whether wisdom was 'acquired', 'created', or 'engendered'. In his typical lateral approach, Loader (2014:345) proposes that wisdom's origin is suggestively referred to here in terms of both 'clarity and vagueness'. It is the multivalence of the Hebrew terms used in verse 22 that caused different readings of the text for centuries, ranging from contemporary literature in rabbinic and Patristic exposition via the 16th-century Melanchton to modern interpreters such as Baumann and Fox. Analysing style and syntax, Loader follows previous divisions and broadens the scope of his commentary by referring to three different groups of interpretations of the term 'amon in the unit of 27-30a: artisan, nurseling, or 'constantly', if interpreted adverbially. Loader (2014:360) argues that the context in which the lexeme is found, having the motifs of fun and laughter, makes the translation of 'nurseling' or 'foster-child' the best choice. Loader (2014:363) joins Melanchton's 16th-century view on the 'aesthetic depth' in 8:22-31 and summarises the depiction of wisdom in this poem as a 'little daughter of Yahweh giving him joy while he is at work' (Loader 2014:361).

This view can be compared to the remarks of his peers. Both Fox and Loader translate the Hebrew qnh in 8:22 with 'create'. Fox indicates that both the versions and later interpretations understood this as reference to wisdom's derivation from Yahwhe and her subordination to him. In Christianity, this term was linked to Christ and interpreted in different ways. Fox admits that it can contextually be translated as either 'created' or 'acquired' (but not as 'possessed'). The word 'designate[s] divine acquisition of wisdom' (Fox 2008:n.p.) and being analogous to the parent's role in procreation, it 'introduces the theme of begetting as the governing metaphor in describing this act of creation' (Fox 2008:n.p.). Loader (2014:345) finds Fox's indication of three optional meanings 'quite remarkable', but takes the argument further. He adds the occurrence of this verb in Genesis 4:1 and 14:19, 22 and the use of it as epithets for Baal and Ashera as further 'instances favouring the meaning "create"' (Loader 2014:347). Loader does not find justification for the translation of this verb as 'bring forth', meaning 'procreation' (Irwin as well as Waltke), neither for Fox's opposing view that it indicates wisdom as an 'accidental attribute to the godhead'. Loader Proverbs 8 on pages $367-375$. discerns between the role ascribed to wisdom in Proverbs $3: 19$ and 8:22ff. In chapter 8 , she is a personified mythical figure and the theme here is that of the excellence of wisdom, projected into primeval times. Wisdom is here 'clearly privileged above other created things' (Loader 2014:348). It is used here in the sense of create to articulate its uniqueness.

Bruce Waltke's commentary as part of the NICOT series (with its scholarly evangelical view of Scripture as the Word of God), integrates the acts and attributes of wisdom in Proverbs 8:22-31 into Christian faith. Woman Wisdom is a type of Jesus Christ (Waltke 2004:127-131). The transliterated qnh of 8:22 stands in the sixth stanza of the interlude in 8:12-31 (cf. Waltke 2004:399-400). It deals with 'her birth in primordial time' (Waltke 2004:406) during God's creation, hence Waltke's understanding of the word in terms of procreation. Waltke's choice of interpretation is substantiated by the dramatic likeness regarding form and concepts with Egyptian texts. Solomon 'invested an Egyptian literary form with Israel's ethical monotheism' (Waltke 2004:408).

Toy (1899:vii) refers in contemporary terms to Proverbs 1-9 as 'philosophical discourses'. Chapter 8 deals with the 'Function of Wisdom as controller of life, and as attendant of Yahweh in the creation of the world' (Toy 1899:vi). He rendered $q n h$ in this 'difficult' text with 'formed (=created)' (Toy 1899:173). In making this decision, he consulted the Hebrew text, 'all the Greek Versions, and the best MS. of the Vulgate' (Toy 1899:173). Gemser's (1963) commentary in the HAT series is of the same technical nature as Toy's commentary and therefore is referred to many times in Loader's technical commentary. Using contemporary research, especially on Egyptian and Sumerian literature, ${ }^{31}$ Gemser (1963:46) translates qnh as 'schuf' (created). Murphy ${ }^{32}$ (1998:48) reads the word together with 'brought forth' in 8:24-25. He deems 'beget' preferable, despite Symmachus', Acquila's, and Theodotion's understanding of the word as 'acquired'.

McKane sides with Von Rad that wisdom has an 'architectonic function in the ordering of the created world' (McKane 1970:351). He translates 8:22a as, 'Yahweh created me at the beginning of his (creative) way' (McKane 1970:223). He understands 'created' in terms of 'procreate' because two other words ('brought forth' 8:24-25 and 'I was formed' McKane 1970:223 in 8:23) are connected with the process of birth (McKane 1970:352). This bears on 8:30ff, in which wisdom is depicted as the 'child of Yahweh' (McKane 1970:353). He does not understand this in terms of Irwin's hypostasis, but rather that wisdom is 'begotten, not made, and is not a creature in the ordinary senses' (McKane 1970:353). Against this background and in dialogue with scholars like De Boer, Ringgren, Irwin, and Donner, McKane (1970:223) translates $8: 30$ as, 'I was beside him as his confidant'.

31.See "Vorwort zur 2. Auflage" (Preface to the second edition) (Gemser 1963:n.p.)."

32.In their Editorial Preface in Murphy (1998:n.p.), the editors say that they suppose that their readers are reading on different levels. The Notes are intended for those who wish to be informed about the textual witnesses on which the translation in who wish to be informed about the textual witnesses on which the translation in the commentary is based. The question, however, remains what use a
have from a publication if some parts are not accessible to him or her. 
Loader consults inter alia the Septuagint, Peshitta, Delitsch, Wildeboer, Ringgren, Murphy, Van Leeuwen, Zabán, Fox, Waltke, Toy, McKane, Plöger, and Tuinstra for one of the possible three translations of the Hebrew 'amon in 8:30. He follows Ibn Janah's analysis and presents the 'celebratory interpretation' (Loader 2014:360) that wisdom is depicted here as a 'nurseling' (in agreement with Rüger), a child at play. Fox uses exactly the same three possible categories. He dialogues with a different set of scholars inter alia Cazelles, Scott, Hoshaya, and Ehrlich. Fox chooses for interpreting the word in terms of 'I was with him growing up' ("āmôn-ing', as it were) (Fox 2008:n.p.). This reading does not need any emendation of the text and stands in harmony with the 'morphology of the Hebrew word' (Fox 2008:n.p.).

Waltke (2004:417) translates 'amon as 'constantly'. There are 'four feasible interpretations' (Waltke 2004:417) for this hapax legomena (single reading). Waltke chooses to read the word in conjunction with 'beside him' in the same verse. The word 'underscores Wisdom's pre-existence to the creation and her close proximity to the Creator at the time' (Waltke 2004:417).

In the 'ternary' verse 30 Toy (1899:177) translates the Hebrew 'amon as 'ward', but concedes that the 'meaning is doubtful'. The translation as ward or nursling 'accords with the succeeding context, and with the representation of the whole paragraph...' (Toy 1899:177-178). Gemser (1963:46) favours the rendition 'Pflegling' (foster child), 'Hätchelkind' (fondling), or 'Liebling' (darling) as best suited to the context.

Murphy takes note of the different interpretations of 'amon in 8:30 by Baumann, Rüger, and Fox. Murphy (1998:48) takes his 'cue' from the book Wisdom of Solomon (Wis 7:21; 13:1) and favours 'crafts(wo)man', and translates the word as 'artisan'. He understands the word in terms of the delight wisdom had in herself and her implicit delight to God (cf. Murphy 1998:53). He is very much influenced by Othmar Keel's relating the delight here to the playing and cartwheeling depicted in Egyptian iconography. $\mathrm{He}$ understands the characterisation of wisdom in Proverbs 8 as "'the revelation of God," not merely the self-revelation of creation' (Murphy 1998:55).

In both cases above ( $q$ nh and 'amon), Loader enjoys the benefit of previous research. What is obvious, however, is that he summarises the published results and then extends the older arguments by adding some arguments of his own, mostly based on his skilfulness in Semitic languages.

Summarising the 'message of the chapter', Loader (2014:367) identifies three dimensions that come together in Prov 8:1-36: a religious, an aesthetic, and a rational aspect, again working with the text on more than one level. Together, they form a poem that the fathers used to teach and convince the 'son' of the credibility of wisdom. This is a much needed re-direction of the purpose of the poem, to read it within the overall structure and not as separate units that can be read Christological. His lateral thinking and contextual sensitiveness enabled the author to keep on track and avoid the bypaths often followed in the exegesis of these words.

\section{Summary}

Loader's commentary is not only technical, but in fact highly technical. He marks out a niche in Proverbs commentary that will be difficult to match. If Amazon (n.d.:n.p.) calls McKane's commentary a 'scholar's work for scholars', Loader's commentary can be called 'a commentary for technical inclined connoisseurs'. It will not enjoy the quantity of readers of popular commentaries looking for daily devotion, but will stand side by side with a commentary like that of Toy for the unforeseeable future. For those trained to read the Bible in its Hebrew form, this commentary will be a treasure of erudition.

\section{Acknowledgements}

Financial support by the NRF for the research for this article is hereby acknowledged.

\section{Competing interests}

The author declares that he has no financial or personal relationships which may have inappropriately influenced him in writing this article.

\section{References}

Amazon, M., n.d., Proverbs (Old Testament Library), viewed 24 February 2016, from http://www.amazon.com/Proverbs-Testament-Library-William-McKane/ $\mathrm{dp} / 0334013410$

Fox, M.V., 2000, Proverbs 1-9: A new translation with introduction and commentary, Anchor Bible 18A, Yale University Press, New York.

Fox, M.V., 2008, Proverbs 1-9: A new translation with introduction and commentary Anchor Bible 18A, Yale University Press, London (Logos Edition).

Gemser, B., 1963, Sprüche Salomos, Handbuch zum Alten Testament Erste Reihe 16, JCB Mohr, Tübingen.

Guidelines for contributors to the Historical Commentary on the Old Testament (HCOT), 2007, unpublished. pdf document.

Irwin, W.A., 1961, 'Where shall Wisdom be found?', Journal of Biblical Literature 80, 133-142.

Krüger, T., 2016, Review James Alfred Loader Proverbs 1-9, RBL 02/2016, viewed 25 February 2016, from http://www.bookreviews.org/pdf/10725_11917

Loader, J.A, 1979, Polar structures in the book of Qoheleth, Walter de Gruyter, Berlin.

Loader, J.A, 2014, Proverbs 1-9, Historical Commentary on the Old Testament, Peeters, Leuven.

Logos, H., n.d., Hermeneia and Continental Commentaries, 69 vols., viewed 24 February 2016, from https://www.logos.com/product/43469/hermeneia-andcontinental-commentaries

Longman, T., III, 2013, Old Testament Commentary Survey, 5th edn., Baker Academic, Grand Rapids, MI.

McKane, W., 1970, Proverbs - A new approach, The Old Testament library, SCM Press, London.

Murphy, R.E., 1998, Proverbs, Word Biblical Commentary Volume 22, Word, Incorporated, Dallas, TX (Kindle Edition).

Olive Tree, n.d., John Phillips Commentary Series, viewed 15 February 2016, from https://www.olivetree.com/store/product.php?productid=17388

Placher, W.C. \& Pauw, A.P., s.a., Series introduction, viewed 15 February 2016, from http://wjkbooks.typepad.com/files/belief_series-intro.pdf

Toy, C.H., 1899, A Critical and Exegetical Commentary on the Book of Proverbs, The International Critical Commentary, T\&T Clark, Edinburgh.

Venter, P.M., 1981, Spreuke, Wysheid en Lewe in Spreuke Een tot Nege [Proverbs, Wisdom and Life in Proverbs one to nine], DD thesis, Faculty of Theology (Section A), University of Pretoria.

Waltke, B.K., 2004, The Book of Proverbs. Chapters 1-15, New International Commentary on the Old Testament, William B. Eerdmans, Grand Rapids, MI.

Whybray, R.N., 1994, Proverbs, New Century Bible Commentary, Eerdmans, Grand Rapids, MI. 